Received March 20, 2016

Revised May 15, 2016

Accepted May 30, 2016

\title{
Revenge of Geopolitics: \\ Rise of China and the Confines of Asian Econophoria
}

\author{
RICHARD JAVAD HEYDARIAN*
}

The paper examines the evolution of the Asian regional security architecture in the past three decades, evaluating relations between China and its neighbors, and considering various approaches in International Relations theory. First, the paper examines the assumptions of liberal institutionalism in the context of "econophoria," assessing its merits in East Asia. Second, the paper addresses China and its relations with the East Asian neighborhood in the latter decades of the 20th century. Third, the paper examines growing territorial tensions between China and its neighbors in the past decade -- and how this undermines regional security and regional integration. Lastly, the paper evaluates the contributions of alternative IR theories such as realism and constructivism in providing a better understanding of China's new assertiveness.

Keywords: China, Econophoria, Liberalism, Interdependence, Maritime Disputes

* Assistant Professor, De La Salle University, Manilla, the Philippines;

E-mail: jrfheydarian@gmail.com

DOI: $10.16934 /$ isr.17.1.201606.155 


\section{INTRODUCTION: BRAVE NEW WORLD}

"The temptation of the moment is to believe that unceasing peace will ensure merely because tired men are determined that there shall be no more war. But international tensions will accumulate again, though slowly at first; there was, after all, a generation of peace after Battle of Waterloo," cautioned Sir Halford J. Mackinder, the father of geopolitics, against naive complacency shortly after World War I (Kaplan 2012, 70).

The even more disastrous World War II, which some historians see as nothing but an unfortunate (and not-so-inevitable) continuation of the first, proved to be a testament to the wisdom of Mackinder's profound wariness with what he saw as post-conflict strategic complacency. The end of the Cold War, however, revived an even more pronounced sense of post-conflict complacency, a powerful mirage indeed, as the world gradually embraced a meta-narrative of continued prosperity, pursuit of absolute gains, and stubborn avoidance of inter-state war. As the collapse of the Soviet bloc became eminent, pundits such as Francis Fukuyama triumphantly underlined how "something very fundamental has happened in world history," thanks to the "the total exhaustion of viable systematic alternatives to Western liberalism" (Fukuyama 1989, 1). Drawing on the works of G. W. F. Hegel via Alexandre Kojève, Fukuyama (1981) argued that the great trans-historical battle for ideological supremacy was now irrevocably settled in favor of democratic capitalism as the end point of history-an ideological terminus. The collapse of the Berlin Wall unleashed an all-consuming euphoria, provoking the keenest minds to (naively) foresee a world where all barriers to globalization-that is to say, the integration of markets along capitalist lines and the diffusion of Anglo-Saxon democratic ideals across civilizational lines-would collapse into oblivion. Soon, what emerged was, in the words of Buzan and Segal (1998), an "econophoria"-the powerful illusion that the sheer force of globalization will not only tame (if not dissipate) individual states' more pugnacious instincts, but also gradually eviscerate belligerence as a means for self-preservation and national development. Thus, the locus of states' strategic calculus, in an age of econophoria, shifts from an obsession with territorial integrity and unremitting attachment to Westphalian sovereignty towards, as Stephen Krasner describes it, "interdependence sovereignty," anchored by market integration, economic growth, and consumer-welfare (Krasner 1999).

Some pundits took the logic of econophoria even further, heralding, even more triumphantly than Fukuyama, a post-national global system. In his influential work, The End of the Nation State: The Rise of Regional Economies, Japanese strategist Keinichi Ohmae essentially pronounced the death of the Westphalian state, emphasizing the centrality of regional economics, thanks to revolutions in information technology and to the growing influence of transnational corporations and local governments in determining the economic trajectory of the post-Cold War world. 
Econophoria, and its underlying policy paradigm and worldview, is largely anchored by International Relations (IR) theories such as liberal-institutionalism, which, towards the end of Cold War, emphasized the shifting physics of power in the international system.

Keohane and Nye (1977), for instance, articulated the emergence of "complex interdependence" among states, where (i) military power is no longer the best mechanism for pursuing strategic ends and at times could be counterproductive; (ii) there is no longer a clear hierarchy of strategic priorities given the growing entwinement of financial-trade and defense interests; and (iii) the expanding role of epistemic communities-and norm entrepreneurs, as some constructivists put itin promoting inter-state cooperation and consolidating supranational organizations, which facilitate, in an increasingly autonomous manner, efforts at mitigating the deleterious, conflict-inducing impact of international anarchy.

As Joseph Nye (2004a, 77) argues, "In general, power is becoming less transferable, less coercive, and less tangible ... Economic interdependence usually carries benefits in both directions; and threats to disrupt a relationship, if carried out, can be very expensive ... use of force has become more costly, so less threatening forms of power have grown increasingly attractive." There is also a discernible shift in the foreign policy bureaucracy. Foreign policy is no longer the exclusive realm of foreign and defense ministers, who are mostly attached to traditional notions of sovereignty, but also of finance and trade ministers, who are focused on enhancing the welfare of their citizens through inter-state cooperation increasingly under the aegis of international regimes (i.e., World Trade Organization). With the diffusion of democratic ideals and the empowerment of a rising middle class, states are under increasing pressure to orient their foreign policies towards cooperation and achievement of absolute gains, rather than obsessively pursue zero-sum competition with (real and perceived) rivals (Hill 2003).

Far from unitary actors, behaving in accordance with the "billiard ball" metaphor, states are, liberals argue, instead under constant pressure to satisfy the needs of domestic consumers and economic actors, who, by and large, support beneficial (and often cordial) intercourse among states. "No-one now believes that foreign policy is unaffected by what occurs within states," Christopher Hill (2003, 219-2020) argues, in Changing Politics of $21^{\text {st }}$ Century, "most tangibly, states must address their own constituents-the 'inside' of their own community, as opposed to the 'outside' for which they have no formal responsibility." "The End of History," therefore, means that there is now a symbiotic relationship between the spread of democracy, which empowers consumer-oriented middle- and aspirational classes, and global capitalism, which is designed to fulfill the insatiable material desires of market societies.

The end of the Cold War marked the age of econophoria, where rising economic interdependence means that (a) inter-state conflict is irrational, expensive, and self- 
defeating; (b) international organizations provide public goods such as information and transparency, lower transactions costs, legally-binding agreements, codes of behavior, and confidence-building through iterated cooperation; (c) increased interaction through markets and their corollary channels of communication, gradually producing a pacifist lobby at home and, on a broader level, a socializing effect that nurtures cosmopolitanism, enhanced mutual-understanding, empathy, and reduction of "Othering" among previously distant societies; (e) cooperation in areas of "low politics" (i.e., free trade deals) creates a positive inertia that "spills-over" into more thorny areas of "high politics" (i.e., defense agreements); and (f) alteration of strategic culture of previously hostile states, promoting a more cooperative calculus among their policy-making elites. In other words, the world has moved closer to a Kantian "perpetual peace" grounded by the deepening of economic linkages, the spread of democratic values, and the emergence of international regimes (Kant 1795, Oye 1985; Keohane 1982; Moravcsik 1997; Axelord and Keohane 1985).

\section{NEW CHINA, NEW ASIA}

North America and Western Europe are conventionally seen as islands of peace, where formerly competing states have created "security communities," and where neighbors have forgone even the threat of use force as a foreign policy tool in their dealings among themselves. Outside the "West," however, East Asia has not only emerged as one of the world's major economic poles, now home to one of the world's largest industrialized economies, but it is also home to vibrant democracies such as Japan, South Korea, and Taiwan, as well as home to a string of performance-based autocracies dedicated to economic development and deeply embedded in international markets.

Has the region also developed-or is on the verge of developing-a Kantian order, where the imperatives of globally-integrated economic growth have dissipated great power politics and ameliorated security dilemma among competing states? Well, that seemed to have been the impression of many, especially since the SinoAmerican détente in the 1970s, amid the emergence of a pragmatic leadership under Deng Xiaoping, which gave birth to an era of explosive growth in China and deepening regional economic integration, led by an ascendant Beijing. This, however, was not possible without a major recalibration in Beijing's relations with its neighbors, with most developed ones (i.e., Japan, South Korea, and Taiwan) largely aligned to the capitalist West, led by the United States.

Beginning in 1979, when Deng consolidated power over the Chinese state apparatus, Beijing progressively normalized relations with estranged neighbors, including Japan and Peninsular Southeast Asia. Over the next three decades, China rapidly transformed itself into the pillar of regional economic integration. Drawing 
lessons from the developmental states of post-Meiji Japan, Park-led South Korea, and Kuomintang-ruled Taiwan, as well as from Tiger $\mathrm{Cub}$ economies such as Singapore, post-Mao China embarked on a national development strategy that was more appreciative of private enterprise, foreign capital and technology, and "winwin" relations with the outside world (Naughton 2006; Shirk 2007; Kissinger 2011; Studwell 2014; Osnos 2014)

After all, Deng, who lamented China's decades-long isolation and economic stagnation under Mao Zedong, fervently believed that "development is the only hard truth ... and if we do not develop, then we will be bullied" (Kissinger 2011). This was not only the beginning of a pragmatic Chinese foreign policy, but also a systematic "charm-offensive" that saw Beijing developing cordial ties, regardless of ideology, with most if not all of its neighbors, including former rivals such as Japan. Econophoria meant an obsession with growth at home and the necessity for cooperative relations abroad. China had to become, following Deng's pragmatic logic, a "responsible stakeholder" or risk confronting a counter-alliance and isolation. Throughout the opening decades of the Cold War, Communist China fought ideological and actual wars against its neighbors. It was involved in the Korean War (1950-1953), fighting on the side of (invading) North Korean forces. It also supported North Vietnam, which sought to conquer the western-aligned Southern Vietnam. And China never stopped using intimidation and military maneuvers to threaten the Kuomintang-ruled Taiwan. Throughout peninsular Southeast Asia, China supported a series of rebel, communist movements, which aimed to topple the national bourgeoisie in post-colonial nations. China was a bogeyman in the eyes of capitalist Asia. Under Chairman Mao, it was primarily ideology rather than economics that guided its foreign policy, especially in East Asia (ibid.)

In fairness, Mao, in his final years, did make some major foreign policy recalibrations, the most prominent of which was his decision to negotiate a SinoAmerican détente in light of growing Soviet threats. He also reached out to powerful neighbors such as Japan. In fact, in 1972, when Mao was still at the helm of the Chinese state apparatus after surviving decades of turmoil under his megalomaniac "Great Leap Forward" and "Cultural Revolution" experiments, China and Japan re-established diplomatic relations. Tokyo, which communicated its willingness to downgrade relations with Republic of China (Taiwan), saw the need for a common front with Beijing against Moscow. Underscoring his willingness to put the past behind and build a new relationship with Japan, Mao, quite astonishingly, foreswore any Japanese reparation for its World War II atrocities, and with his abled deputy, Premier Zhou Enlai, emphasized the necessity of focusing on areas of common interest rather than conflict. (Next to Russia, China was the largest victim of atrocities committed by Axis powers.) Pleased by China's magnanimity and its call for a new type of relationship, Japan, in a joint communiqué, openly 
professed its remorse over past atrocities and acknowledged its "keenly conscious responsibility for the serious damage that Japan caused in the past to the Chinese people through war, and deeply reproaches itself' (Shirk 2007: 158-159). Seen in this light, Deng, the new paramount leader of China, simply built on the foundation laid down by his predecessor (Shirk 2007; Kurlantzick 2007; Kissinger 2011).

In 1978, Deng made a fateful visit to Japan, the first visit of its kind. And he meant business, going so far as asking Japanese experts to serve as Beijing's economic advisers, which paved the way for the creation of Sino-Japanese Economic Knowledge Exchange Association. They also signed a Treaty of Peace and Friendship, building on the ashes of decades of hostile bilateral relations, beginning in the late- $19^{\text {th }}$ century and culminating during World War II. There was a conscious effort to remember past atrocities but in a spirit of forgiveness and reconciliation. Elated by the thaw in Sino-Japanese relations and eager to communicate Tokyo's remorse over past atrocities, Japanese Prime Minister Yasuhiro Nakasone considered revising Japan's controversial historical textbooks in order to more accurately reflect the country's World War II atrocities against people of China (Shirk 2008, 159-160).

The normalization of diplomatic relations undergirded a blossoming economic relationship, with Japan arguably serving as an engine of Chinese industrialization. In the 1979-1999 period, Japan, through the Overseas Economic Cooperation Fund (OECF), provided as much as $\$ 25$ billion in grants and loans to China. Meanwhile, Japan's External Trade Organization (ETO) helped establish training programs by Japanese firms about to engage in (limited) technology transfer schemes and capital investment ventures in China. More crucially, in the 1979-1999 period, the Overseas Economic Cooperation Fund (OECF), Japan's state development financing agency, provided almost US\$25 billion in soft loans to China, while Japan's External Trade Organization (ETO) facilitated the establishment of training programs by Japanese firms to facilitate capital investment in and (limited) technology transfer to China (Keck 2014).

Under Deng's guidance, (economic) relations with Taiwan, considered as a renegade province by Beijing, also blossomed. In its initial phase of economic liberalization, China mostly relied on Chinese investments from Hong Kong and Southeast Asia, but Taiwan would soon play an increasingly important role in Mainland industrialization. This was possible due to the deftly-negotiated "Consensus of 1992," whereby both sides agreed that there was only one China, but agreed to disagree on whether the leadership in Taipei or the Chinese Communist Party was the ultimate sovereign (Shirk 2007). It was a perfectly symbiotic relationship. Rising labor costs in Taiwan meant that geographically-proximate, populous China could help Taiwanese manufacturers maintain their competitiveness in an increasingly tight international market. Taiwanese Foreign Direct Investments (FDI) in China 
jumped from around \$20 million in 1986 to a whopping US\$9.9 billion in 1993. By the mid-1990s, Taiwan was a leading investor on the Mainland, committing as much as $\$ 40$ billion (5 percent of Taiwan's entire Gross Domestic Product) to China's burgeoning industries. (Brown et al. 2010, 13). The pragmatic Deng also made historic visits to America and Southeast Asia, re-oriented China's foreign policy by advocating renewed trade and investments relations with neighboring countries (Shirk 2007; Kurlantzick 2007; Kissinger 2011). Deng also institutionalized his pragmatic foreign policy, poignantly captured by his now-famous dictum: "hide your strength, bide your time" (Kissinger 2011).

Towards the end of his life, Deng supported efforts by his protégé, Jiang Zemin, to embark on a charm offensive in the Asian neighborhood. China began to forward a "vision of a multilateral security community in Asia that presents an alternative that competes with the U.S.-led arrangement of 'hub-and-spokes' alliances with Japan, South Korea, Australia, and Thailand" (Shirk 2007: 129). Quite ambitiously, Chinese strategists, under the aegis of an empowered and nimble Foreign Ministry, advocated a "new security concept" based on cooperation, equality, mutual benefit, and mutual trust. China was in effect pushing for a quintessential Westphalian utopia, where great power politics, military interventions, and political interference are supplanted by a harmonious, post-ideological system based on economic intercourse and cordial diplomatic relations. In a 1999 speech at the United Nations Committee on Disarmament, President Jiang argued against "the old security concept based on military alliances and buildup of armaments" in favor of the "new security concept that meets the need of the times" (ibid). The "need of the times," of course, was economic development, anchored by comprehendsive cooperation and minimum inter-state friction. It was a classic econophoric argument, where economics is the crux of politics and the bedrock of international relations. Under Jiang's watch, China's diplomats became, Sinologist Susan Shirk (2007: 127) argues, "more and more positive about multilateral organizations as a means to enhance China's reputation as a responsible power."

In fairness, this was not hot air or a rhetorical concoction. China made a concerted effort to resolve its territorial disputes, especially with all continental neighbors. In his critically acclaimed book Strong Borders, Secure Nation: Cooperation and Conflict in China's Territorial Disputes, Taylor Fravel shows how China settled border disputes with the Central Asia republics of Tajikistan, Kyrgyzstan, Kazakhstan, and with Russia, a historical rival since the time of Czars, as well as with south-eastern neighbors such as Vietnam and Laos. Astonishingly, across the majority of these border deals, China settled for only half or less of its original claim, with countries like Tajikistan only ceding 1,000 out of 28,000 square kilometers of contested areas in the Pamir mountains (Fravel and Medeiros 2003; Steele 2013). The situation was a bit more complicated in Southeast Asia, where China squared off with at least four countries: the Philippines, Malaysia, Vietnam, 
and Brunei. In 1995, China sparked a diplomatic crisis when it occupied, in the preceding year, the Philippine-claimed Mischief Reef in the Spratly Islands in the southern portion of the South China Sea. But China was able to repair relations with the Philippines and upgrade its image among its smaller neighbors when, under the aegis of the Association of Southeast Asian Nations (ASEAN), it acquiesced to the 2002 Declaration on the Conduct of Parties in the South China Sea (DOC), which, among other things, encouraged claimants to avoid the threat or use of force to consolidate their claims, and to resolve their disputes through peaceful, diplomatic means. China and ASEAN also agreed that the DOC would have to be followed by a legally-binding Code of Conduct (COC), to provide the precise parameters for managing and resolving maritime disputes. As a form of confidence-building measure, if not a permanent "solution," China proposed the "win-win" formula of "joint development" in contested areas in order to allow claimant states to put aside zero-sum debates on sovereignty in favor of positivesum ventures of oil and gas exploration, ecological research and preservation, and fisheries resources exploitation (Kurlantzick 2007; Shirk 2007).

China also began to advocate and/or create new cooperative arrangements, beginning with the Shanghai Cooperation Organization (SCO), the Conference on Interaction and Confidence-Building Measures in Asia (CICA), and ASEAN Regional Forum (ARF). China also became an active participant and support of ASEAN-Plus arrangements with major powers. The SCO and CICA provided China with a platform to enhance cooperation with continental neighbors, facilitating China's broader economic push into Russia, Central Asia, South Asia, and the Middle East. The ARF and ASEAN, meanwhile, allowed China to build trust and confidence with many of the world's most prosperous and promising economies, many of which were allies and strategic partners of the United States. The SCO and CICA also allowed China to build stronger ties with post-Soviet Russia, while the ASEAN-led initiatives helped China deepen its ties with the United States, Japan, and smaller powers. China's multilateral activism was a poignant reflection of a new era of complex interdependence in Asia. China also became a key component of the Six Party Talks aimed at de-nuclearizing the Korean Peninsula. In 2006, China even participated in an America-organized joint naval exercise in the Sea of Japan. The exercise aimed to showcase great powers' unity in their counter-proliferation objectives (ibid). As Fravel and Medeiros (2003) explain, China "expanded the number and depth of its bilateral relationships, joined various trade and security accords, deepened its participation in key multilateral organizations, and helped address global security issues."

Under Jiang's successor, Hu Jintao, who was also a protégé of Deng, China pushed the envelope by embracing a "peaceful development" strategy. He also adopted Joseph Nye's concept of "soft power." In his much- celebrated book Soft Power: The Means to Success in World Politics, Harvard academic Joseph Nye 
emphasized the centrality of preference-shaping, persuasion and attraction in global leadership. For Nye, "sources of power are, in general, moving away from emphasis on military force and conquest" (Nye 2004a, 55). In an era of globalization, what is important is "to set the agenda and attract others in world politics, and not only force them to change by threatening military force or economic sanctions" (Nye 2004b, 5).

"Culture has become a more and more important source of national cohesion and creativity and a factor of growing significance in the competition in overall national strength," Hu declared, making an observation not too dissimilar from Nye's views, in a keynote speech to the 17th National Congress of the Communist Party of China (CPC) in 2007. He called upon China to "enhance culture as part of the soft power of China to better guarantee the people's basic cultural rights and interests" (Xinhua 2007). Under his watch, China expanded the Confucius Institutes-quasi-academic centers tasked with promoting China's image through teaching language and culture-across the world. Over the next decade, China would spend as much as $\$ 10$ billion annually on promoting its image and points of view through state-owned/guided media and academic institutions (Shambaugh 2015).

In short, China was now advocating a new regional order based on concepts of "peaceful development" and "win-win" cooperation. As Matt Ferchen (2015) explains: "This framework is based on a purported virtuous circle ... where China's continued economic development depends on a peaceful and stable domestic and international environment. And, in turn, China's continued development will contribute to international peace, security, and prosperity." In fact, "China has continued to promote a 'community of common destiny' in its own neighborhood ... The logic of such ... is based on the proposed link between mutually beneficial economic growth and enhanced regional stability and security," Ferchen continues. Some Sinologists, particularly Joshua-Cooper Ramo and Stefan Halper, went so far as to declare the emergence of the so-called "Beijing Consensus"-an econophoria in accordance to China's pragmatic conception of the world. China's preferred order, Sinologists argue, stood in opposition to the western-imposed "Washington Consensus," which is based on misguided policy prescriptions benefiting western interests but ravaging developing-emerging economies along the way (CooperRamo 2004; Jacques 2013).

Crucially, there was a quantitative basis to the expectations of an increasingly Sino-centric order. Within a decade, from 2001 to 2011, China's cumulative pledges in foreign development assistance (FDA) reached almost $\$ 700$ billion, with a large portion of it destined for the major ASEAN countries of Indonesia, Malaysia and Thailand (Wolf et al. 2013). Between 2003 and 2012, China's trade with ASEAN expanded more than six fold, reaching $\$ 400$ billion, while investments topped $\$ 100$ billion. China became the top-trading partner of almost all East Asian countries, with the notable exception of the Philippines (Parameswaran 2013). 


\section{REVENGE OF HISTORY}

All under heaven, however, was not as harmonious as it appeared. Within China, and in its relations with some neighboring countries, tensions and contradictions gradually built up to a boiling point. China's rapid economic growth, coupled with accelerated military modernization, created new expansionist dialectics, since, as Kaplan (2010) explains, as "states become stronger, they cultivate new needs and-this may seem counterintuitive-apprehensions that force them to expand in various forms."

Soon it became clear that the Asian security architecture, anchored by American hegemony, was more fragile than initially thought. East Asia was not necessarily following in the footsteps of post-Cold War West. It was not building an inclusive security community. Developments within China and in its relations with a number of its maritime neighbors gradually began to chip away at the hopes of creating a Kantian order in Asia.

Domestically, post-Tiananmen China was gradually consumed by a wave of aggrieved nationalism, mainly thanks to the introduction of the Patriotic Education program, which instilled in the Chinese national psyche a perpetual sense of victimhood, redemptive anger, and revanchism. As Zhao (1998, 287) explains: "The patriotic education campaign was a state-led nationalist movement, which redefined the legitimacy of the post-Tiananmen leadership in a way that would permit the Communist Party's rule to continue on the basis of a non-Communist ideology." What started as an opportunistic maneuver to "bolster CCP power in a country that was portrayed as besieged and embattled," instead led to an explosion in "nationalistic sentiment of the Chinese people" over the years (ibid). Conseuently, China's relations with some neighbors were bound to suffer, since the outcome included anti-Japanese sentiments and a popular embrace of revanchism, particularly vis-à-vis China's long-dormant territorial claims in adjacent waters (Shirk 2007; Kissinger 2014; Hayton 2014).

Shifts in Beijing's economic needs also encouraged growing Chinese maritime assertiveness in adjacent waters. Amid a booming economy, domestic resources could no longer meet China's insatiable demand for hydrocarbon resources and basic commodities, so the country began to import the bulk of its fossil fuel-based energy resources from abroad. As the "world factory," especially for low-valueadded manufacturing products, China also transformed itself into a leading trading nation, building vast networks of economic linkages across all corners of the globe. This encouraged Beijing to gradually build up its naval capabilities in order to better protect its strategic imports, communication channels, and foreign investments, especially in an event of crisis, whether within a trading-investment partner or/and between Beijing and its geopolitical rivals such as India, America and its allies. In November 2003, Hu advanced the concept of oil security, favoring the development 
of an advanced naval fleet that could protect the country's energy and trade interests (Li 2010).

The 1990s and 2000s also saw a gradual shift in the geography of Chinese power. As Robert Kaplan (2010) explains, unlike during the Cold War when Beijing was primarily concerned with its northern-continental frontier, China began "consolidating its land borders and began to turn outward ... Thanks to this favorable situation on land, China was now free to work at building a great navy." In fact, under Jiang and $\mathrm{Hu}$, China experienced a rapid military build-up, with the bulk of new acquisitions and defense spending dedicated to its naval fleet, particularly the South Sea Fleet-a burgeoning armada oriented towards the South China Sea. The discovery of and/or speculation over the presence of large hydrocarbon reserves, in addition to its rich fisheries resources, made adjacent waters like the South and East China Sea even more strategic in the eyes of Chinese leaders, who, amid an explosion of popular-aggrieved nationalism, viewed adjacent waters as an extension of China's national territory, its "blue soil" (Li 2010: Kaplan 2010; Hayton 2014).

To complicate matters, China, up until the Xi Jinping administration, also lacked a proper bureaucratic mechanism to coordinate its maritime policies. During the $\mathrm{Hu}$ administration, multiple law enforcement agencies, which were eager to expand their jurisdictional boundaries, as well as local government units (e.g., Hainan and Fujian), which were bent on expanding their access to fisheries resources in adjacent waters, aggressively pushed the boundaries of China's territorial claims across the South China Sea (Li 2010; International Crisis Group 2012b; Ruwitch 2014; Erickson and Collins 2013; Erickson and Kennedy 2015).

Deepening economic ties between China and her neighbors also concealed another important element: the lack, if not total absence, of a durable, rule-based regional security architecture. As Bzrezinski $(1998,153)$ succinctly puts it: "although surpassing Europe in economic development, Asia is singularly deficient in regional political development. It lacks the cooperative multilateral structures that so dominate the European political landscape and that dilute, absorb, and contain Europe's more traditional territorial, ethnic, and national conflicts ... Asia is today the seat of the world's greatest concentration of rising and recently awakened mass nationalisms ..." Echoing Bzrezinski, Kissinger $(2014,212)$ explains that in "Asia, almost every state is impelled by its own dynamism. Convinced that it is 'rising,' it operates with the conviction that the world has yet to affirm its full deserved role." China, of course, is the largest and most consequential of all the aspirational Asian states.

After the signing of the DOC in 2002, there was hardly any concerted effort by ASEAN to push for a legally-binding COC in the South China Sea. Nor did China express any willingness to be bound by regionally-derived normative arrangements. China's ambitions, one could argue, were largely held in check by the presence of American naval might, which has guaranteed freedom of navigation in international 
waters since the end of World War II. The Great Recession of 2008, which undermined the foundations of American economic and military power, suddenly provided a unique strategic opening for China to assert its long-held claims in adjacent waters, including in the East China Sea, where China and Japan have conflicting claims over the Senkaku (Diaoyu to Chinese) Islands (Luttwak 2012; Hayton 2014; Pillsbury 2015).

Beginning in 2010, China ramped up its naval and para-military patrols across adjacent waters. In the East China Sea, a seemingly mundane incident rapidly evolved into a diplomatic crisis, torpedoing decades of careful efforts aimed at establishing a mutually satisfactory arrangement over the disputed Senkaku islands. When the Japanese Coast Guard captured a Chinese fisherman, who straddled close to the Japanese-occupied Senkaku Islands, Beijing stridently demanded his immediate and unconditional release. Amid a diplomatic standoff, China even signaled its willingness to cut off Japan's access to Chinese rare earth metals. Under pressure, Japan eventually relented, but hardliners in both capitals upped the ante, demanding total surrender from the other side. Tokyo's then-governor, the firebrand Shintaro Ishihara, also upped the ante, proposing to purchase the contested features, which for a long time had been owned by private nationals, in order to bolster the country's claims and dispense with any question as to which country owns the Senkaku Islands. To pre-empt the hardline government of Tokyo, the national government, led by the center-left Democratic Party of Japan (DPJ), instead "nationalized" the islands by purchasing them itself, sparking massive anti-Japan protests in China, which led to the extensive destruction of Japanese-made products, properties, and investments on the Mainland. Bilateral trade and investment ties suffered, as Beijing began to squeeze Japanese investors through dubious legal cases and Tokyo began to search for alternative investment destinations under a “China Plus One" strategy (Katz 2013; Chang 2013; Pyle 2014).

Meanwhile, territorial tensions deepened as China began to dispatch a growing number of aircrafts and military and para-military vessels close to the Japanesecontrolled Senkaku islands. By 2013, a new right-wing government, led by former Prime Minister Shinzo Abe, was in power. The Abe administration responded by beefing up Japan's defense spending, augmenting Japanese military presence in the East China Sea, and, quite controversially, gradually chipping away at the pacifist constitutional restrictions on Japan's ability to project military power. This abrupt deterioration in bilateral ties is even more astonishing when one recalls how not long ago, the two Asian juggernauts showed determination to overcome their territorial disputes and historical animosities in favor of robust trade and investment relations (Pyle 2014).

Back in 2008, for instance, Japanese Prime Minister Yasuo Fukuda and his Chinese counterpart, President $\mathrm{Hu}$, issued a joint statement, declaring the East China Sea to be "a Sea of Peace, Cooperation and Friendship." The following 
month, Fukuda's foreign minister, Masahiko Komura, announced a preliminary agreement aimed at, first, the joint-development of hydrocarbon resources and, second, the delimitation of overlapping claims in the East China Sea (Szechenyi 2015). Bilateral relations entered an even more cordial era, when the DPJ assumed power in a dramatic election in 2009 that saw a progressive party, led by Yukio Hatoyama, ending decades of Liberal Democratic Party (LDP) hegemony. Prime Minister Hatoyama, amid much fanfare, promised to revisit Japan-US security alliance on an equal partnership basis, adopt a more independent Japanese foreign policy, and reset relations with neighbors such as China in order to establish an "East Asian community" of peace and harmony. (Hemmings 2010). As bilateral relations deteriorated, and the two giants sleepwalked towards conflict, some observers, including leading policy-makers, were quick to warn about the potential repeat of World War I. "This year marks the centenary of World War I. Britain and Germany were highly (inter)dependent economically. They were the largest trade partners (to each other), but the war did break out," Prime Minister Shinzo Abe warned during the 2014 World Economic Forum in Davos. "What I would call a military encounter between Japan and China would deal great damage to both countries. Its regional and global impact would be extremely large" (Asahi Shimbun 2014). A poisonous rhetoric began to cloud Sino-Japanese relations.

The situation is no better in the South China Sea, where Beijing has been squaring off against multiple smaller neighbors, particularly the Philippines and Vietnam. Similar to the East China Sea disputes, there is nothing new with these cases in the South China Sea. For the past century, Chinese scholars, and later political leaders (both Kuomintang and the Communist Party), have openly claimed the area as part of China's national territory, ostensibly because of Beijing's supposed "historical rights." Throughout the Cold War period, China-sensing America's waning commitment to its ally in Saigon-coercively usurped South Vietnam-occupied land features in the Paracel Islands in 1974, and later, in 1988, engaged in skirmishes against Vietnam in the Spratly Islands, as the Soviet Union decoupled from its mutual defense treaty with Hanoi. By 1994, when American military bases were removed from Subic and Clark, China wrested control of the Philippine-claimed Mischief Reef in the Spratly Islands (Kaplan 2014; Hayton 2014).

From 2010 onwards, however, the disputes reached a fever pitch. The upsurge in the disputes could actually be traced back to the May, 2009 decision of Vietnam and Malaysia to submit, despite vigorous Chinese opposition, their (bumped out) sovereignty claims in the South China Sea to the UN Commission on the Limits of the Continental Shelf (CLCS), which is in charge of evaluating whether certain coastal states can extend their claims beyond their 200-nautical-miles Exclusive Economic Zone (EEZ). In China's view, the two ASEAN countries violated an implicit modus vivendi-not to "internationalize" the maritime disputes-by submitting their claims to third party arbitration bodies. In response, China submitted a 
Note Verbale to the United Nations, accompanied by its notorious nine-dash line claim, which covers much of the South China Sea. By 2010, during the ARF, America stepped into the fray and openly declared its opposition to further Chinese territorial assertiveness in the area, with neighboring countries such as Vietnam and the Philippines openly criticizing China's intrusion into their claimed waters. Secretary of State Hillary Clinton declared that America has an interest in freedom of navigation in the area, effectively accusing China of stoking tensions and undermining maritime security in one of the world's most important Sea Lines of Communications (SLOCs). But China refused to back down, perhaps calculating that by now, under the Obama administration and amid an economic crunch, postcrisis America no longer had the wherewithal to check China's ambitions. Believing that it had legitimate claims across the entire basin, China was also incensed by ongoing efforts of neighboring countries such as the Philippines and Vietnam to develop offshore hydrocarbon resources (within their EEZs in the contested waters). Things came to head in 2011, when China stepped up its efforts at disruptting energy exploration/development activities by smaller claimant states, even if they were within their EEZs and far beyond China's own. That year saw at least saw five incidents involving Chinese surveillance vessels harassing Philippine energy exploration activities within its own EEZ, particularly in the energy-rich Reed Bank (International Crisis Group 2012b; Kaplan 2014).

The following year, the Philippines and China found themselves in a precarious naval standoff over the Scarborough Shoal, which is located within the Philippines' EEZ but not that of China. To avoid military clashes, and panicking over China's decision to impose economic sanctions against the Philippines, Manila decided to engage in a mutual-disengagement agreement, just to see China effectively occupying the contested feature and cordoning off the waters surroundding it (International Crisis Group 2012a; 2012b). Outgunned and desperate to defend its territorial claims, in 2013 the Philippines decided to file an arbitration case against China and negotiate a new security agreement with the United States, the Enhanced Defense Cooperation Agreement (EDCA). Similar to Sino-Japanese relations, bilateral economic relations suffered, while high-level communication channels effectively collapsed. To this date, Philippine President Benigno Aquinowho, on two occasions, likened China to Nazi Germany-has not held a single formal summit with his Chinese counterpart, Xi Jinping (Heydarian 2015).

China's relations with Vietnam, a fellow communist country, also dramatically deteriorated due to the uptick in South China Sea disputes, especially when China decided to dispatch a giant oil rig into Vietnamese-claimed waters, first in 2014 and later in 2016. In response, Vietnam threatened to, similar to the case of the Philippines, file an arbitration case against China. Vietnam also implored the ASEAN and broader international community to condemn what it saw as China's unlawful behavior, and Vietnam upgraded its security and economic relations with the United 
States, India and Japan (Abuza 2014; Vuving 2015). China made international headlines when, beginning in late 2013, it embarked on a massive reclamation project across the South China Sea, creating artificial islands and major dualpurpose facilities on former rocks and atolls. In response, the United States, beginning in October 2015, conducted Freedom of Navigation (FON) patrols close to Chinese-controlled features, sparking a tit-for-tat "militarization" dynamic between Washington and the United States. In response to American FON operations, China enhanced its military presence in disputed waters, dispatching surface-toair-missiles systems, high-frequency radars, and fighter jets to (artificially-created) islands in the South China Sea (Heydarian 2016).

Rising territorial tensions in the region have undermined confidence in the existing regional security architecture, which is led militarily by the United States and steered diplomatically under the aegis of the ASEAN. Economic relations between China and some of its neighbors, particularly Japan and the Philippines, have also suffered. In fact, the United States and some of its Asian allies have also come to treat China's ostensibly economic initiatives such as infrastructure development, particularly under the aegis of the newly-created Beijing-based Asian Infrastructure Investment Bank (AIIB), as part of a supposed Chinese strategy to gain an economic leverage over neighboring states. Japan, for instance, has totally shunned membership in the AIIB, while the Philippines signed up only at the $11^{\text {th }}$ hour after months of excruciating reluctance (Ferchen 2016). Above all, however, there are growing concerns that rising tensions in the region will eventually sparkaccidentally, and akin to the origins of World War I-a full-scale military conflict in the region. As China's claims to "peaceful rise" lose luster-with opinion polls suggesting that majority of people in most countries in the region are deeply worried about the possibility of war over maritime disputes in the area (Global Attitudes Survey 2014). Many people have lowered their expectations that Asia will follow Western Europe and North America in creating a security regime, anchored by thick networks of international organizations, trade linkages, and post-nationalism cosmopolitan values. In short, the Asian regional order is far from stable, and China's rise has put tremendous stress on the existing American-led security architecture, with potentially frightening ramifications.

\section{CONCLUSIONS}

Not long after the collapse of the Soviet Union, Samuel Huntington (1996) cautioned against the limits of peace-inducing dividends of economic interdependence. "People define their identity by what they are not," Huntington $(1996,67)$ argued, "As increased communications, trade, and travel multiply the interactions among civilizations people increasingly accord greater relevance to their civilization identity." While his controversial arguments about the impending "clash of civili- 
zations" continues to be a point of heated debate, his insights are relevant to exposing the illusions engendered by econophoria. In fact, as Dale Copeland argues, economic interdependence "can either be peace-inducing or war-inducing, depending on the expectations of future trade," meaning it matters if states "expect that high trade levels will continue into the foreseeable future" (ibid). As China decouples from Japanese investments and technology, it may increasingly take its economic relations with Tokyo for granted (Chang 2013). In the years preceding World War I, Germany and Britain were leading trading partners, but this did not stop them from sleepwalking into carnage. Most of the time, economic interdependence is asymmetrical, meaning that one party is less dependent on the other. There is also little guarantee that economic interdependence sustains the influence of pro-trade lobbies and rational-pacifist voices within the state. No wonder, John Maynard Keynes, who closely observed the era of high globalization before the great conflicts of the $20^{\text {th }}$ century, expressed his doubts vis-à-vis the limits of rational "financial calculation" in shaping interstate relations. Growing economic interdependence, Keynes (1933) explained, is "likely or certain in the long run to set up strains and enmities which will bring to naught the financial calculation." In fact, some scholars would argue that World War I was not the product of a sudden outburst in irrational instincts, but instead the sub-optimal (and disastrous) collective outcome of seemingly rational, piecemeal escalation among competing, mutually-distrustful powers (Nye 2004a).

The dangerous flare up in territorial tensions between China and its maritime neighbors underscores the limits of economic interdependence in taming the Freudian "death drive" instincts of nation-states, particularly rising powers like China. More than two millennia ago, Greek historian Thucydides, analyzing the roots and evolution of the Peloponnesian War, explained how powerful states are motivated by not only self-interest, but also by fear/ambition and honor/pride. The tragic hegemonic showdown between Athens and Sparta, Thucydides explained, revealed that the "true underlying cause of war was reason's failure to constrain" primal instincts of pride and fear, with Athens falling under the weight of its "hubris and policies based more on hope than reason" (Lebow 2007, 169).

In many ways, Thucydides' "realist" description of inter-state relations, particularly between rising powers (e.g., Sparta, China) and established ones (e.g., Athens, Japan, America), can help us understand the seemingly abrupt and precarious uptick in territorial tensions in East Asia. One can understand China's rising territorial assertiveness as a reflection of its desire to maximize its security by dominating its own backyard. This will allow China to dominate key SLOCs, create a buffer against external predation, and gain access to precious natural resources in adjacent waters. After all, as Mearsheimer (2014) explains, "the best way to survive in international anarchy is to be the sole regional hegemon."

As explained earlier, there are also ideational factors that may explain the 
shift in China's behavior. Constructivists such as Alexander Wendt, for instance, have contributed to a better understanding of the endogenous dynamics behind the formation of interest and changes in the behavior of states, specially amid periods of rapid domestic change and/or reconfigurations in the international system. As Wendt explains:

The exceptional, conscious choosing to transform or transcend roles has at least two preconditions. First, there must be a reason to think of oneself in novel terms. This would most likely stem from the presence of new social situations that cannot be managed in terms of pre-existing self-conceptions. Second, the expected costs of intentional role change-the sanctions imposed by others with whom one interacted in previous roles-cannot be greater than its rewards. When these conditions are present, actors can engage in selfreflection and practice specifically designed to transform their identities and interests and this "changes the games" in which they are embedded" (Wendt 1992, 407-420).

Overseeing decades of rapid economic change, accelerated military modernization, and state-constructed popular nationalism, an increasingly confident China is recalibrating its conception of and its position in the regional order (Allison 2015). With respect to territorial disputes with Japan, for instance, China seems keen on "correcting" what it sees as a historical injustice by trying to reverse setbacks during its 100 Years of Humiliation. As McCormack (2013) explains:

From China's viewpoint, a single line may be drawn from Ryukyu (1879), Senkaku/Diaoyu (1895), Taiwan (1895), to Dongbei or "Manchuria" (1931) ... International law offered no system to which aggrieved colonial or semicolonial countries could appeal and no such recourse was open to Chinawhether the Republic (whose capital moved from Nanjing to Taiwan in 1949) or the People's Republic (from 1949) - until the time it was actually shown, when the withdrawal of US forces from Okinawa became imminent and focused attention on what was and what was not "Okinawa" and to whom it should be "returned."

On the surface, the Senkaku islands appear as a bunch of worthless rocks, which hardly merit the risk of military escalation between two Asian juggernauts. Japan and China are among each other's leading trade and investment partners, and yet they have allowed festering disputes to undermine their high-stakes economic linkages. Instead of econophoria, what one sees, therefore, is a showdown between two proud nations, one that is rising, China, and one that has suffered decades of stagnation, Japan (McCormack 2013). The Senkaku disputes have gained outsized 
geopolitical importance, becoming objects of contestation, as the two powers try to assert/shift the regional pecking order. In the South China Sea, meanwhile, China is reclaiming what it deems as its national "blue soil," gradually transforming one of the world's most important SLOCs into a de facto domestic lake (Holmes 2015). Amid this tectonic shift in the regional balance of power, the Asian order is moving from away from what seemed like a "permissive" anarchy, where thickening economic linkages pave the way for the emergence of security communities, towards a more self-help, predatory form of anarchy, where balance of power, pride, and fear dominate inter-state relations.

\section{REFERENCES}

Abuza, Zackary. 2014. "Vietnam Buckles Under Chinese Pressure," in Asia Times Online, 29 July, 2014, accessed August 1, 2015, www.atimes.com/atimes/ Southeast_Asia/SEA-01-290714.html.

Axelrod, Robert and Robert Keohane. 1985. "Achieving Cooperation under Anarchy: Strategies and Institutions." World Politics 38(1): 226-254.

Brown, Kerry et al. 2010. Investment Across the Taiwan Strait: How Taiwan's Relationship with China Affects its Position in the Global Economy. London: Royal Institute of International Affairs.

Brzezinski, Zibnew. 1998. The Grand Chessboard: American Primacy and its Geostrategic Imperatives. New York: Basic Books.

Buzan, Barry and Gerald Segal. 1998. "Rethinking East Asian Security." in Rising Powers Initiative, accessed May 24, 2016, http://www.risingpowersinitiative. org/wp-content/uploads/buzan.pdf.

Chang, Gordon. 2014. "The Chinese and Japanese Economies Are Delinking: Prelude to Conflict?" In Forbes, 16 February, 2014, accessed www.forbes.com/si tes/gordonchang/2014/02/16/the-chinese-and-japanese-economies-are-delink ing-prelude-to-conflict/.

Cooper-Ramo, Joshua. 2005. The Beijing Consensus. London: Foreign Policy Centre. Erickson, Andrew, and Gabe Collins. 2013. New Fleet on the Block: China's Coast Guard Comes Together. Wall Street Journal, 11 March, accessed www.blogs.wsj.com/chinarealtime/2013/03/11/new-fleet-on-the-blockchinas-coast-guard-comes-together/.

Erickson, Andrew and Conor Kennedy. 2015. "China's Island Builders: The People's War at Sea." Foreign Affairs, 9 April.

Ferchen, Matt. 2016. "China Keeps the Peace: How Peaceful Development Helps and Hinders China." Foreign Affairs, March 8.

Fravel, Taylor and Evan Medeiros. 2003. "China's New Diplomacy." Foreign Affairs, November/December.

Fukuyama, Francis. 1989. "The End of History?” The National Interest 16: 3-18. 
Global Attitudes Survey. 2014. "How Asians View Each Other." Washington DC: Pew Research Center, July 14, accessed http://www.pewglobal.org/2014/07/ 14/chapter-4-how-asians-view-each-other/.

Hayton, Bill. 2014. The South China Sea: The Struggle for Power in Asia. London: Yale University Press.

Hemmings, John. 2010. "Understanding Hatoyama's East Asian Community Idea." in East Asia Forum, Australian National University, 22 January, accessed www.eastasiaforum.org/2010/01/22/understanding-hatoyamas-east-asian-com munity-idea/.

Heydarian, Richard Javad. 2015. "The Diplomatic Implications of PhilippinesChina Arbitration." In Asia Maritime Transparency Initiative. Center for Strategic and International Studies, January 21.

Heydarian, Richard Javad. 2016. "The End of U.S. Primacy in Asia." The National Interest, March 3.

Hill, Christopher. 2003. The Changing Politics of Foreign Policy. Basingstoke: Palgrave Macmillan.

Huntington, Samuel. 1996. The Clash of Civilizations and the Remaking of World Order. New York: Simon and Schuster.

International Crisis Group. 2012a. "Stirring up the South China Sea (I): Regional Responses." Brussels: International Crisis Group, accessed January 1, 2014, www. crisisgroup.org/ /media/Files/asia/north-east-asia/223-stirring-up-thesouth-china-sea-i.pdf.

International Crisis Group. 2012b. "Stirring up the South China Sea (II): Regional Responses." Brussels: International Crisis Group, accessed January 1, 2014, www. crisisgroup.org/ /media/files/asia/ north-east-asia/229-stirring-up- thesouth-china-sea-ii-regional- responses.pdf.

Jacques, Martin. 2012. When China Rules the World: The End of the Western World and the Birth of a New Global Order. New York: Penguin Books.

Kant, Immanuel. 1795 (1983). Perpetual Peace. In Perpetual Peace and Other Essays. New York: Hackett.

Kaplan, Robert. 2009. "Center Stage for the 21st Century: Power Plays in the Indian Ocean." Foreign Affairs, March/April.

Kaplan, Robert. 2010. "The Geography of Chinese Power.” Foreign Affairs, May/ June.

Kaplan, Robert. 2012. The Revenge of Geography: What the Map Tells Us About Coming Conflicts and the Battle Against Fate. Random House: New York.

Kaplan, Robert. 2014 Asia's Cauldron: The South China Sea and the End of a Stable Pacific. New York: Random House.

Katz, Richard. 2013. "Why Chinese-Japanese Economic Relations Are Improving." Foreign Affairs, 30 December.

Keck, Zachary. 2014. "China's Communist Party and Japan: A Forgotten History." 
in The National Interest, May 27, accessed www.nationalinterest.org/feature/ chinas-communist-party-japan-forgotten-history-10533.

Keohane, Robert O. and Joseph S. Nye. 1987. "Power and Interdependence Revisited." International Organization 41: 725-753.

Keohane, Robert. 1982. "The Demand for International Regimes." International Organization 36(2): 325-355.

Keohane, Robert O. and Joseph S. Nye. 1977. Power and Interdependence: World Politics in Transition. Boston: Little, Brown and Co.

Keynes, John Maynard. 1933. "National Self-Sufficiency." The Yale Review 22(4): 755-769.

Kissinger, Henry. 2011. On China, New York: Penguin Books.

Kissinger, Henry. 2014. World Order. New York: Penguin Books.

Klare, Michael and Yogesh Chandrani. 1994. World Security: Challenges for a New Century. New York: St. Martin's Press.

Krasner, Stephen.1999. Sovereignty: Organized Hypocrisy. New Jersey: Princeton University Press.

Kurlantzick, Joshua. 2007. Charm-Offensive: How China's Soft Power is Transforming the World. New York: Yale University Press.

Lebow, Ned Lebow. 2007. "Thucydides and Deterrence." Security Studies 16(2): 163-188

Li, Nan. 2010. "Chinese Civil-Military Relations in the Post-Deng Era: Implications for Crisis Management and Naval Modernization." US Naval War College, January, accessed www.usnwc.edu/Research-Gaming/China-Mari-time-Stu dies-Institute/Publications/documents/China-Maritime-Study-No-4-January2010.aspx.

Luttwak, Edward. 2012. The Rise of China vs. the Logic of Strategy. Belknap Press: New York.

McCormack, Gavan. 2013. "Much Ado over Small Islands: The Sino-Japanese Confrontation over Senkaku/Diaoyu." Asia-Pacific Journal 11(21).

Mearsheimer, John. 2014. "Can China Rise Peacefully?" The National Interest, 25 October, accessed nationalinterest.org/commentary/can-china-rise-peacefully10204.

Moravcsik, Andrew. 1997. "Taking Preferences Seriously: A Liberal Theory of International Politics." International Organization 51(4): 513-553.

Moravcsik, Andrew. 2003. "Liberal International Relations Theory: A Scientific Assessment." In Progress in International Relations Theory: Appraising the Field edited by Colin Elman and Miriam F. Elman. Boston: MIT Press.

Naughton, Barry. 2006. The Chinese Economy: Transitions and Growth. Cambridge, MA: MIT Press.

Nye, Joseph. 2004a. Power in the Global Information Age. Routledge: New York.

Nye, Joseph. 2004b. Soft Power: The Means to Success in World Politics. New 
York: Public Affairs.

Osnos, Evan. 2014. Age of Ambition: Chasing Fortune, Truth, and Faith in the New China. New York: Farrar, Straus and Giroux.

Oye, Kenneth. 1985. "Explaining Cooperation under Anarchy: Hypotheses and Strategies." World Politics 38(1): 1-24.

Parameswaran, Prashanth. 2013. "Beijing Unveils New Strategy for ASEAN-China Relations." in The Jamestown Foundation 13(21), 24 October, accessed www. jamestown.org/single/?tx_ttnews[tt_news]=41526\&no_cache $=1 \#$. VK6ZM 3uGPT8.

Pillsbery, Michael. (2015). The Hundred-Year Marathon: China's Secret Strategy to Replace America as the Global Superpower. Henry Holt: New York.

Pyle, Kenneth. 2014. "The Sea Change in Japanese Foreign Policy." in National Bureau of Asian Research, accessed www.nbr.org/publications/element. aspx?id $=747$.

Ruwitch, John. 2014. "Satellites and Seafood: China Keeps Fishing Fleet Connected in Disputed Waters." Reuters, 27 July, accessed http://www.reuters.com/arti cle/us-southchinasea-china-fishing-insight-idUSKBN0FW0QP20140728.

Shambaugh, David. 2015. "China's Soft-Power Push: The Search for Respect." Foreign Affairs, July/August.

Shirk, Susan. 2007. China: Fragile Superpower. Oxford: Oxford University Press.

Steele, Jonathan. 2013. "China in the Stans." London Review of Books 35(20): 33-34. Studwell, Joe. 2014. How Asia Works. New York: Grove Press.

Szechenyi, Nicholas. 2015. "Platform of Mistrust: Natural Resource Development in East Asia." Asia Maritime Transparency Initiative. Center for Strategic and International Studies, August 5.

Xinhua. 2007. "Hu Jintao Calls for Enhancing Soft Power of Chinese Culture." Xinhua New Agency, 15 October, accessed www.news.xinhuanet.com/eng lish/2007-10/15/content_6883748.htm.

Vuving, Alexander. 2015. "A Breakthrough in US-Vietnam Relations." The Diplomat, 10 April, accessed www.thediplomat.com/2015/04/ a-breakthrough-inus-vietnam- relations/.

Wendt, Alexander. 1992. "Anarchy is What States Make of It: The Social Construction of Power Politics." International Organization 46(2): 391-425.

Wolf, Charles, Xiao Wang and Eric Warner. 2013. "China's Foreign Aid and Government Sponsored Investment Activities: Scale, Content, Destinations, and Implications." Rand Corporation, National Defense Research Institute, Washington, DC, accessed http://www.rand.org/content/dam/rand/pubs/research_ reports/RR100/RR118/RAND_RR118.pdf.

Zhao, Susheng. 1998. "A State-led Nationalism: The Patriotic Education Campaign in Post-Tiananmen China." Communist and Post-Communist Studies 31(3): 287-302. 